\title{
ANALISIS YURIDIS PERSIDANGAN PERKARA PIDANA SECARA ELEKTRONIK
}

\author{
${ }^{1}$ Siti Nurhaliza, ${ }^{2}$ Romi Asmara, ${ }^{2}$ Johari \\ e-mail : siti.170510023@mhs.unimal.ac.id \\ ${ }^{1}$ Mahasiswa Fakultas Hukum Universitas Malikussaleh \\ ${ }^{2}$ Dosen Fakultas Hukum Universitas Malikussaleh
}

\begin{abstract}
The government responded to the Covid-19 pandemic conditions in Indonesia by issuing rules regarding the trial of criminal cases electronically. In carrying out the trial electronically, the defendant must continue to carry out the trial conducted in prison. But what about the defendant who tested positive for Covid-19. Therefore, the researcher wants to examine the procedure for conducting an electronic trial against a defendant who is positive for Covid-19 and what efforts will be made by law enforcement against a defendant who is positive for Covid-19. The purpose of this study is to discuss the implementation of electronic trials for defendants who are infected/positive for COVID-19, then discuss the obstacles and efforts in implementing electronic trials for defendants who are infected/positive for COVID-19, whether they are in accordance with the rights of the defendant. This method uses a qualitative method with an empirical juridical approach, in other words the type of sociological legal research is a research procedure that produces descriptive data in the form of written words or direct interviews with related parties. Based on the results of the study, it was found that the implementation of the electronic trial of criminal cases against defendants who were positive for Covid-19 was carried out with the implementation stage, namely the stage of ratifying the Supreme Court regulations against the electronic trial of Perma Nomor 4 of 2020 concerning the administration and trial of criminal cases electronically, especially in the Lhokseumawe district court class IB in April 2020 and regarding the implementation of defendants who were positive for COVID-19, the procedure for which there are no rules in Perma Nomor 4 of 2020 concerning administration and trial of cases electronic crime. For example, the health officer should have a special doctor who treats positive defendants, and the infrastructure should be more complete. Suggestions to law enforcement are to explain to the suspect/defendant clearly the rights of the accused, both his own rights and the right of the accused to conduct a trial in court.
\end{abstract}

Key Word: Teleconference Meeting, Defendant, COVID-19. 


\section{PENDAHULUAN}

Pada tahun 2020 dalam Revolusi 4.0, yang mana ditandai dengan merebaknya wabah pandemi Corona Virus Deasess 2019 atau disingkat dengan COVID-19 adalah cengkraman wabah yang paling mematikan dalam beberapa tahun terakhir berdampak besar terhadap berbagai aspek kehidupan. Untuk mencegah terjadinya penularan yang berdampak besar pemerintah menerapkan untuk memakai masker, menjaga kebersihan lingkungan, mencuci tangan, dan menjaga jarak oleh karena itu Penegakan hukum sangat berdampak. Khususnya dalam melaksanakan hukum acara pidana. Sejumlah penegak hukum berupaya mencari jalan keluar dalam mengatasi keterbatasan penegakan hukum dan berpekara pidana agar terhindar dari penularan Covid-19.

Ketiga institusi penegak hukum Makamah Agung, Kejaksaan Dan Kemenkumham, akhirnya menjalin kerjasama yang dituangkan dalam Perjanjian Kerjasama Nomor: 402/DJU/HM.01.1/4/2020, Nomor: KEP-17/E/Ejp/04/2020, Nomor: PAS-08.HH.05.05 Tahun 2020 tanggal 13 April 2020 Tentang Pelaksanaan Persidangan Melalui Teleconference (Reda Manthovani,2020). Persidangan melalui Teleconference atau disebut dengan Persidangan secara elektronik adalah serangkaian proses memeriksa, mengadili, dan memutus perkara terdakwa oleh pengadilan yang dilaksanakan dengan dukungan teknologi informasi dan komunikasi, audio visual dan sarana elektronik lainnya.

Pelaksanaan persidangan daring tentu tidak lepas dari catatan positif maupun negatif ditemukan masalah seperti kualitas sinyal internet yang tidak stabil, kualitas suara atau audio yang tidak bagus sehingga dapat mengganggu jalannya persidangan, seharusnya membentuk tim pengawas dan mengevaluasi pelaksanaan persidangan daring, serta menerapkan protokol kesehatan di lingkungan pengadilan (Andita Rahma,2020).

Namun lagi-lagi, landasan hukum yang ada harus diperkuat. Perlu diketahui, Undang-Undang Nomor 8 tahun 1981 tentang KUHAP harus segera di revisi. Pengaturan proses persidangan secara elektronik tidak cukup hanya melalui perjanjian kerjasama, surat edaran institusi maupun Peraturan Mahkamah Agung sekalipun. Pasalnya hal tersebut menyangkut pemenuhan hak asasi saksi dan terdakwa.

Sebelumnya proses persidangan perkara pidana yang diatur dalam hukum acara pidana di Indonesia dilakukan melalui tatap muka atau secara langsung Hakim, Jaksa, Terdakwa, dan Penasihat Hukum di dalam ruang sidang pengadilan. Kehadiran secara fisik terdakwa dan saksi di ruang sidang pengadilan diatur dalam Pasal 185 ayat (1) dan Pasal 189 ayat (1) KUHAP. Pasal 185 ayat (1) KUHAP menyebutkan, "Keterangan saksi sebagai alat bukti ialah apa yang saksi nyatakan di sidang pengadilan". Sedangkan Pasal 189 ayat 1 KUHAP menyebutkan, "Keterangan terdakwa ialah apa yang terdakwa nyatakan di sidang tentang perbuatan yang ia lakukan atau yang ia ketahui sendiri atau alami sendiri".

Pengertian keterangan terdakwa adalah lebih luas dibanding dengan pengakuan terdakwa, sehingga dengan memakai keterangan terdakwa dapat dilakukan lebih maju dari pada pengakuan terdakwa karena yang menjadi alat bukti adalah keterangan terdakwa bukan keterangan tersangka yakni keterangan terdakwa yang diberikan dalam persidangan peradilan. Lalu bagaimana dengan terdakwa yang terinfeksi/positif Covid-19 haruskah persidangan secara elektronik tetap dijalankan/dilaksanakan dan harus di tunda untuk sementara waktu atau ditiadakan. Adakah hak terdakwa dalam kondisi terinfeksi/positif Covid-19 dalam persidangan secara elektronik. 
Sebelum Covid-19 terjadi apabila terdakwa mendadak sakit di persidangan karena alasan yang sah maka akan dianggap tidak layak untuk disidangkan atau majelis Hakim akan mengeluarkan penetapan untuk mengembalikan berkas perkara kepada penuntut umum. Sebagaimana diatur dalam Pasal 54 KUHAP.

Namun bagaimana dengan terdakwa yang positif Covid-19 apakah persidangan harus ditunda atau tetap dilangsungkan dikarenakan persidanganya dilakukan secara elektronik (Daring). Melihat banyaknya proses persidangan yang dilakukan secara online tersebut membuat pihak Ombudsman memonitoring. Hasilnya, ditemukan adanya kendala teknis dalam penyelenggaraan persidangan daring di 16 pengadian Negeri salah satunya di Pengadilan Negeri Lhokseumawe. Walau demikian, pandemi Covid-19 menjadi alasan kuat untuk menggelar Persidangan Perkara Pidana Secara Elektronik. Pengadilan Negeri Lhokseumawe Kelas 1B telah memutus pekara daring sebanyak 117 (seratus tujuh belas ) perkara pidana secara elektronik dan 11 (sebelas) diantaranya yang terkena Covid-19 pada tahun 2020 .

\section{METODE PENELITIAN}

Adapun metode penelitian yang dipergunakan dalam penelitian implementasi persidangan perkara pidana secara elektronik dan kendala atau upaya terhadap pelaksanaan tersebut menggunakan metode jenis penelitian yuridis empiris yaitu penelitian lapangan, data yang didapat melalui kegitan observasi dan wawancara yang didukung oleh pengumpulan data secara studi pustaka (Bambang Sunggono,2007:81) Penelitian ini peneliti menggunakan pendekatan kualitatif yaitu merupakan prosedur penelitian yang menghasilkan data deskriptif berupa kata-kata tertulis atau tulisan dari orang-orang dan perilaku yang diamati dan berupa untuk mencari makna atau "verstehen". dikembangkan berdasarkan hasil penelitian lapangan, secara langsung peneliti melakukan penelitian kepada sumber data/responden. Penelitian ini bersifat deskriptif dan analisis, yang mana merupakan studi untuk menemukan fakta dengan interpretasi yang tepat.

Sumber data dalam penelitian ini yaitu Data primer yang diperoleh di lapangan melalui hasil wawancara langsung dengan informan dan responden dan Data sekunder atau data penunjang dalam penelitian ini yaitu melalui studi kepustakaan dengan cara pengumpulan data berbagai sumber normatif yang berkaitan dengan Permasalahan yang diteliti. Oleh karena itu Teknik pengumpulan data peneliti yaitu merupakan cara-cara yang dilakukan oleh peneliti untuk mengumpulkan data. cara pengumpulan data ini dapat dilakukan melalui teknik penelitian dokumen/literature dan teknik penelitian lapangan. Pengumpulan data juga dilakukan melalui peraturan perundang-undangan, serta klasifikasi dan sistematisasi bahan hukum sesuai Permasalahan penelitian. Oleh karena itu, teknik pengumpulan data yang digunakan dalam penelitian ini adalah dengan studi kepustakaan dan penelitian lapangan. Studi kepustakaan dilakukan dengan cara membaca, menelaah, mencatat membuat ulasan bahan-bahan pustaka. Studi lapangan dilakukan dengan wawancara terhadap responden dan informan.

Dalam penelitian ini peneliti mengambil lokasi penelitian di Pengadilan Negeri kelas IB Lhokseumawe, Kepolisian Resor Lhokseumawe dan lembaga pemasyarakatan kelas IIA Lhokseumawe. Pengambilan lokasi ini dengan pertimbangan bahwa sumber data di lokasi tersebut memungkinkan untuk dilakukan penelitian yang berkaitran dengan Persidangan Perkara Pidana Secara Elektronik. 


\section{HASIL PENELITIAN DAN PEMBAHASAN}

\section{A. Implementasi Persidangan secara elektronik Terhadap Terdakwa Yang Terinfeksi/Positif Covid-19.}

persidangan secara elektronik adalah serangkaian proses memeriksa, mengadili, dan memutus perkara terdakwa oleh pengadilan yang dilaksanakan dengan dukungan teknologi informasi dan komunikasi, audio visual dan sarana elektronik lainnya. Persidangan secara elektronik masih terjadi berbagai Permasalahan. Salah satunya kasus terdakwa yang terkena Covid-19 di Pengadilan Negeri Lhokseumawe Kelas I B. untuk itu peneliti ingin menguraikan sedikit implementasi pelaksanaan persidangan secara daring terhadap terdakwa yang terinfeksi/positif Covid-19.

\section{Tahapan Pengesahan Peraturan Makamah Agung Terhadap Persidangan Elektronik}

Ketiga institusi penegak hukum Makamah Agung, Kejaksaan Dan Kemenkumham, akhirnya menjalin kerjasama yang dituangkan dalam Perjanjian Kerjasama Nomor: 402/DJU/HM.01.1/4/2020, Nomor: KEP-17/E/Ejp/04/2020, Nomor: PAS-08.HH.05.05 Tahun 2020 tanggal 13 April 2020 Tentang Pelaksanaan Persidangan Melalui Teleconference. Berdasarkan hasil keputusan rapat pimpinan Makamah Agung menimbang bahwa pengadilan berkewajiban membantu pencari keadilan dan berusaha mengatasi segala hambatan dan rintangan untuk mewujudkan peradilan yang sederhana, cepat dan biaya ringan. Pembaruan peradilan 2010-2035 diantaranya bertujuan untuk mewujudkan peradilan yang modern berbasis teknologi informasi dengan adanya perkara yang terkendala keadaan tertentu membutuhkan penyelesaian secara cepat dengan tetap menghormati hak asasi manusia oleh karena itu Makamah Agung menetapkan Peraturan Makamah Agung Republik Indonesia Nomor 4 Tahun 2020 Tentang Administrasi Dan Persidangan Perkara Pidana Di Pengadilan Secara Elektronik.

Namun lagi-lagi, landasan hukum yang ada harus diperkuat. Perlu diketahui, UndangUndang Nomor 8 tahun 1981 tentang KUHAP harus segera di revisi. Pengaturan proses persidangan secara elektronik tidak cukup hanya melalui perjanjian kerjasama, surat edaran institusi maupun Peraturan Mahkamah Agung sekalipun. Pasalnya hal tersebut menyangkut pemenuhan hak asasi saksi dan terdakwa. diatur dalam Pasal 185 ayat (1) dan Pasal 189 ayat (1) KUHAP.

\section{Pelaksanaan persidangan secara elektronik terhadap pada masa pandemi Covid-19}

Berdasarkan wawancara dengan Budi Sunanda S.H.,M.H salah satu mejelis Hakim Pengadilan Negeri Lhokseumawe Kelas I B mengenai persidangan secara elektronik pada masa pandemic covid-19 ada beberapa tahapan pelaksanaan yaitu:

a. Mengenai Ruang Sidang Secara Elektronik dan Keberadaan Para Pihak Dalam Ruang Sidang Pengadilan.

b. Dokumen Elektronik.

c. Pelimpahan Perkara dan Panggilan Sidang secara Elektronik.

d. Pelaksanaan Persidangan secara elektronik

e. Dakwaan keberatan/ Eksepsi secara elektronik.

f. Pemeriksaan Saksi, Ahli dan terdakwa secara elektronik

g. Pemeriksaan barang bukti

h. Adapun Tuntutan, Pembelaan, Replik Dan Duplik persidangan secara elektronik 
i. Pemberitahuan putusan dan Putusan secara elektronik

j. Kendala Teknis dan Akses Publik

Table 1 statistik Pengadilan Negeri Lhokseumawe kelas I B yang telah melakukan implementasi persidangan daring pada tanggal 07 April 2020-11 Februari 2021

\begin{tabular}{|c|l|c|}
\hline No & $\begin{array}{c}\text { Jenis Perkara/ kasus Persidangan } \\
\text { secara Elektronik }\end{array}$ & $\begin{array}{c}\text { Jumlah Perkara } \\
\text { Persidangan } \\
\text { elektronik }\end{array}$ \\
\hline 1 & Narkotika & 82 \\
\hline 2 & Pencurian & 45 \\
\hline 3 & Penggelapan & 9 \\
\hline 4 & Penganiayaan & 7 \\
\hline 5 & Kdrt & 4 \\
\hline 6 & Perdagangan Orang & 7 \\
\hline 7 & Perlindungan Anak & 4 \\
\hline 8 & Penadahan & 5 \\
\hline 9 & Senjata Api/Benda Tajam & 4 \\
\hline 10 & Ancaman Kekerasan & 1 \\
\hline 11 & Pemalsuan Surat & 13 \\
\hline 12 & Penipuan & 2 \\
\hline 13 & Perkara Anak & 186 \\
\hline & JUMLAH & \\
\hline
\end{tabular}

Sumber: Pengadilan Negeri Lhokseumawe 2021.

Dari tabel diatas dapat disimpulkan bahwa:

1) Jumlah kasus perkara pidana yang melakukan persidangan secara elektronik 13 jenis perkara pidana.

2) Jumlah keseluruhan perkara yang melangsungkan persidang secara elektronik 186 perkara.

3) Jenis perkara tertinggi kasus narkotika dengan jumlah perkara 83 dan jenis perkara terendah kasus pemalsuan surat dengan jumlah 1 perkara.

4) Jumlah Rata-rata Persidangan secara elektronik yaitu 14 perkara pidana secara elektronik.

\section{Pelaksanaan persidangan secara elektronik terhadap terdakwa yang positif Covid-} 19.

Sebelum Covid-19 terjadi apabila terdakwa mendadak sakit di persidangan karena alasan yang sah maka akan dianggap tidak layak untuk disidangkan atau majelis Hakim akan mengeluarkan penetapan untuk mengembalikan berkas perkara kepada penuntut umum. Sebagaimana diatur dalam Pasal 54 KUHAP. Menurut pendapat peneliti tentang pelaksanaan persidangan secara daring terhadap terdakwa yang positif Covid-19, pelaksanaan tersebut bisa saja dilakukan apabila terdakwa bersedia dan terdakwa juga dalam kategori Orang Tanpa Gejala asalkan sesuai dengan aturan berikut:

a. Melakukan uji coba Rapid Tes Antigen. 
b. Setelah melakukan rapid Test kemudian dilanjutkan dengan Test Swab polymerase chain reaction (PCR).

c. Pelaksanaan Persidangan Secara Elektronik Di Tunda Sementara.

d. Ruang Pelaksanaan Persidangan Secara Elektronik Terhadap Terdakwa Covid-19

e. Fasilitas Yang Digunakan Saat Persidangan Elektronik Terhadap Terdawa Covid-19

3.1.1 Data Terdakwa Yang Terkena Covid Dalam Persidangan Secara Elektronik Perkara Pidana Pada Tanggal 07 April 2020-11 Februari 2021

\begin{tabular}{|c|c|c|c|}
\hline NO & NO PERKARA & TERDAKWA & KASUS \\
\hline 1 & 198/Pid.Sus/2020/PN Lsm & $\begin{array}{l}\text { Akbar Nurkarim Bin } \\
\text { Hasanuddin }\end{array}$ & Narkotika \\
\hline 2 & 205/Pid.B/2020/PN Lsm & $\begin{array}{l}\text { Andri Fauzi Bin Alm. } \\
\text { Samsul Anwar }\end{array}$ & Pencurian \\
\hline 3 & 250/Pid.B/2020/PN Lsm & $\begin{array}{l}\text { Wahyuinsani Bin Abdul } \\
\text { Mais }\end{array}$ & Pencurian \\
\hline 4 & 02/Pid.Sus/2021/PN Lsm & $\begin{array}{l}\text { Muhammad Bin } \\
\text { Jamaluddin Hasan }\end{array}$ & Narkotika \\
\hline 5 & 03/Pid.Sus/2021/PN Lsm & Basri Sihombing & $\begin{array}{l}\text { Perdagangan } \\
\text { Orang }\end{array}$ \\
\hline 6 & 04/Pid.B/2021/PN Lsm & Mansyur Bin Alm.Sulaiman & Pemalsuan Surat \\
\hline 7 & 05/Pid.Sus/2021/PN Lsm & $\begin{array}{l}\text { M. Jauhari Bin Abdul } \\
\text { Manaf }\end{array}$ & $\begin{array}{l}\text { Senjata } \\
\text { Api/Benda Tajam }\end{array}$ \\
\hline 8 & 06/Pid.Sus/2021/PN Lsm & $\begin{array}{l}\text { Nunung Fauziah Bin } \\
\text { Sumarno }\end{array}$ & $\begin{array}{l}\text { Perdagangan } \\
\text { Orang }\end{array}$ \\
\hline 9 & 08/Pid.Sus/2021/PN Lsm & Junaidi Bin Sulaiman & $\begin{array}{l}\text { Senjata } \\
\text { Api/Benda Tajam }\end{array}$ \\
\hline 10 & 12/Pid.Sus/2021/PN Lsm & M. Feri Bin Fauzi Cs & Narkotika \\
\hline 11 & 13/Pid.Sus/2021/PN Lsm & $\begin{array}{l}\text { Haris Munadi Alias Is Bin } \\
\text { Mukhtar }\end{array}$ & Narkotika \\
\hline 12 & 15/Pid.Sus/2021/PN Lsm & $\begin{array}{l}\text { Fauzan Ismi Bin Nasron } \\
\text { S.E }\end{array}$ & Narkotika \\
\hline 13 & 16/Pid.Sus/2021/PN Lsm & $\begin{array}{l}\text { Mughayatsyah Bin Ridwan } \\
\text { Hasyim }\end{array}$ & Narkotika \\
\hline 14 & 17/Pid.Sus/2021/PN Lsm & Sunardi Bin Syaifuddin & Narkotika \\
\hline 15 & 18/Pid.Sus/2021/PN Lsm & $\begin{array}{l}\text { Khairul Zaman Bin Ahmad } \\
\text { Yusuf }\end{array}$ & Narkotika \\
\hline 16 & 19/Pid.Sus/2021/PN Lsm & $\begin{array}{l}\text { Imam Maulana Bin Zakaria } \\
\text { Cs }\end{array}$ & Narkotika \\
\hline 17 & 20/Pid.Sus/2021/PN Lsm & $\begin{array}{l}\text { Wanda Abubakar Bin Abu } \\
\text { Bakar Cs }\end{array}$ & Narkotika \\
\hline 18 & 21/Pid.Sus/2021/PN Lsm & Alfian Bin Zakaria A Gani & Narkotika \\
\hline 19 & 22/Pid.Sus/2021/PN Lsm & Jalaluddin Bin Ibrahim & Narkotika \\
\hline 10 & 23/Pid.Sus/2021/PN Lsm & Zakarea Bin Ilyas & $\begin{array}{l}\text { Perdagangan } \\
\text { Orang }\end{array}$ \\
\hline 21 & 24/Pid.Sus/2021/PN Lsm & Dani Al Fajar Bin Syahrizal & $\begin{array}{l}\text { Perdagangan } \\
\text { Orang }\end{array}$ \\
\hline 22 & 26/Pid.B/2021/PN Lsm & Junaidi Bin Alm.Iskandar & Pencurian \\
\hline 23 & 27/Pid.B/2021/PN Lsm & $\begin{array}{l}\text { Noprizal Alias Adek Bin } \\
\text { M.Isa }\end{array}$ & Pencurian \\
\hline
\end{tabular}




\begin{tabular}{|l|l|l|l|}
\hline 24 & 28/Pid.B/2021/PN Lsm & M. Ridwan Bin Hasan & Pencurian \\
\hline 25 & $30 /$ Pid.B/2021/PN Lsm & Heri Maulizar Bin M.Yusuf & Pencurian \\
\hline 26 & $42 /$ Pid.Sus/2021/PN Lsm & $\begin{array}{l}\text { M.Yusuf Fadillah Bin } \\
\text { Sunardi }\end{array}$ & Narkotika \\
\hline 27 & $47 /$ Pid.Sus/2021/PN Lsm & Nasrullah Bin Syaifuddin & Narkotika \\
\hline
\end{tabular}

Sumber: Pengadilan Negeri Lhokseumawe 2021

Dari keterangan tabel diatas bahwa data terdakwa yang positif Conona Virus Deases (COVID) 2019 yaitu 27 (dua puluh tujuh) perkara. Jenis perkara pidana terbanyak adalah jenis perkara pidana khusus dengan jumlah 17 perkara dengan kasus terbanyak yaitu narkotika.

\section{B. Kendala Dan Upaya Dalam Implementasi Persidangan Perkara Pidana Secara Elektronik Terhadap Terdakwa Yang Terinfeksi/Positif Covid-19}

Melihat banyaknya proses persidangan yang dilakukan secara online tersebut membuat pihak Ombudsman memonitoring. Hasilnya, ditemukan adanya kendala teknis dalam penyelenggaraan persidangan daring di 16 pengadian Negeri salah satunya di Pengadilan Negeri Lhokseumawe. Walau demikian, pandemi Covid-19 menjadi alasan kuat untuk menggelar Persidangan Perkara Pidana Secara Elektronik. Pengadilan Negeri Lhokseumawe Kelas 1B telah memutus pekara daring sebanyak 117 (seratus tujuh belas ) perkara pidana secara elektronik dan 11 (sebelas) diantaranya yang terkena Covid-19 pada tahun 2020 .

\section{Kendala dalam Implementasi Persidangan Perkara Pidana Secara Elektronik Terhadap Terdakwa Yang Terinfeksi/Positif Covid-19}

a. Belum adanya peraturan yang tegas dan jelas mengenai persidangan secara elektronik terhadap terdakwa yang positif Covid-19.

b. Kurangnya pengetahuan dan kemampuan terdakwa maupun saksi dalam administrasi perkara pidana secara elektronik terhadap terdahwa yang positif Covid-19.

c. Dokter Khusus Untuk Terdakwa Positif Covid-19 Yang Melakuakan Sidang Secara Elektronik.

d. Sarana dan prasarana persidangan secara elektronik terhadap terdakwa yang positif Covid-19.

e. Masalah Teknis jaringan tidak stabil dalam persidangan secara elektronik.

Menurut peneliti kendala yang dihadapi dalam persidangan secara elektronik pelaksanaan sidang secara elektronik masih relatif tertutup karena akses untuk mengikuti jalannya proses persidangan secara elektronik hanya diberikan kepada para pihak yang berperkara dan belum terbukan untuk diakses oleh publik dan Kendala yang terakhir menurut penulis yaitu Kendala Teknis berkaitan dengan SDM dan sarana-prasarana jaringan internet yang kurang stabil sehingga proses persidangan secara elektronik tertunda.

\section{Upaya dalam Implementasi Persidangan Perkara Pidana Secara Elektronik Terhadap Terdakwa Yang Terinfeksi/Positif Covid-19 \\ a. Upaya pertama,}


Upaya awal yang harus dilakukan oleh pemerintah atau Ketua Makamah Agung merivisi KUHAP Perma Nomor 4 tahun 2020 tentang Administrasi dan Persidangan Perkara Pidana di Pengadilan Secara Elektronik. Landasan hukumnya harus diperkuat. Pasalnya hal b. Upaya Kedua,

Upaya yang harus dilakukan oleh penegak hukum atau Pihak Petugas Pengadilan Negeri Lhokseumawe agar terlaksananya persidangan secara elektronik terhadap terdakwa yang positif Covid-19. Meskipun tidak diatur dalam KUHAP dan PERMA Upaya yang dilakukan dalam pelaksanaan persidangan secara elektronik adalah melakukan rapat pimpinan dan kerja sama antara pihak Pengadilan Negeri lhoseumawe dan pihak Kejaksaan. Kemudian pihak Kejaksaan dengan Polres Lhokseumawe agar terwujudnya persidangan secara elektronik dengan baik agar hak-hak asasi tercapai dan sesuai dengan KUHAP dan Perma Nomor 4 tahun 2020 tentang administrasi dan persidangan perkara pidana di pengadilan secara elektronik. tersebut menyangkut pemenuhan hak asasi saksi dan terdakwa.

c. Upaya ketiga,

Upaya yang harus dilakukan oleh penegak hukum Kejaksaan meberikan ruangan dan tempat sesuai dengan sarana dan prasarana seperti memberikan fasilitas seperti tempat, hp dan menyediakan Alat Pelindung Diri (APD) untuk berlangsungnya proses persidangan sebagaimana yang dimaksud dalam (Pasal 7) Perma Nomor 4 Tahun 2020.

d. Upaya keempat,

penegak hukum penyidik, Kejaksaan dan Pengadilan Negeri Lhokseumawe menyediakan Dokter Khusus untuk Terdakwa Positif Covid-19 Yang Melakuakan Sidang Secara Elektronik sebagaimana yang dimaksud dalam (Pasal 58 KUHAP) terdakwa yang dikenakan penahanan berhak menghubungi dan menerima kunjungan dokter pribadinya untuk kepentingan kesehatan baik yang ada hubungannya dengan proses perkara maupun tidak.

e. Upaya kelima,

pengacara/penasihat hukumnya sering kali menutut agar proses penuntutan dilakukan secara cepat karena hal tersebut merupakan hak terdakwa yang dijamin oleh undangundang maupun konstitusi, sehingga pengadilan dalam keadaan tertentu harus dilaksanakan persidangan secara online jarak jauh atau teleconference. Menurut penulis penasihat hukum seharusnya lebih mengupayakan kesehatan tersangka atau terdakwa karena terdakwa memiliki hak atas dirinya sendiri (Pasal 55 KUHAP). Apabila terdakwa sakit parah akibat Covid-19 maka seharusnya penasihat hukum terdakwa mengajukan pembantaran sebagaimana yang dimaksud dalam Surat Edaran Makamah Agung Nomor 1 Tahun1989.

f. Upaya keenam,

penegak hukum penyidik, Kejaksaan maupun Pengadilan Negeri Lhokseumawe mengsosialisasikan/ memberitahukan mengenai hak-hak terdakwa apa yang seharusnya dimiliki agar tedakwa mengetahui hak asasi mereka sebagai terdakwa karena sebelum ada putusan yang ingkrah terdakwa masih dinyatakan tidak bersalah.

g. Upaya ketujuh,

pemerintah perlu pengalokasikan dana yang cukup guna pengobatan terdakwa yang sakit parah akibat wabah Covid-19 yang memerlukan dana besar untuk biaya pengobatan. Bagi golongan terdakwa yang tidak mampu diharapkan mendapatkan keringanan biaya, yang dirasa berat bantuan ini merupakan wujud perlindungan hak asasi manusia dalam menyelamatkan jiwa terdakwa. 
h. Upaya kedelapan,

Aparat penegak hukum harus benar-benar selektif dalam melaksanakan persidangan secara elektronik khususnya untuk terdakwa yang positif Covid-19.

Menurut pendapat penulis terhadap upaya untuk mengatasi kendala subtansif maupun tenis perlu dicarikan solusinya agar persidangan secara elektronik dapat dilaksanakan dengan baik. Untuk upaya mengatasi kendala subtansif perlu diatur dengan baik UndangUndang, oleh karena itu harus ada perubahan terhadap KUHAP atau membentuk UndangUndang sendiri yang mengatur acara persidangan secara elektronik sedangkan upaya untuk kendala teknis, perlu menyediakan SDM IT dengan jumlah yang memadai dan meningkatkan pemahaman IT aparat penegah hukum, dan menyediakan sarana dan prasarana pendukung termasuk ketersedian jaringan internet. Sehubungan dengan hal itu penting bagi DPR RI mengajukan inisiatif RUU tentang acara persidangan secara elektronik atau perubahan KUHAP agar persidangan secara elektronik dapat diatur dengan baik. Selain itu penting untuk upaya DPR RI mengalokasikan anggaran agar ada ketersediaan sarana dan prasarana secara elektronik secara memadai disemua lembaga pengadilan da nada anggaran untuk meningkatkan pemahaman IT aparat penegak hukum. Juga mementingkan hak-hak terdakwa khususnya positif Covid-19.

\section{KESIMPULAN}

Implementasi persidangan perkara pidana secara elektronik terhadap terdakwa yang positif Covid-19 dilakukan dengan 3 (tiga) tahap pelaksanaan yaitu tahapan pengesahan peraturan Makamah Agung terhadap persidangan elektronik Perma Nomor 4 tahun 2020 tentang administrasi dan persidangan perkara pidana secara elektronik khususnya pada Pengadilan Negeri Lhokseumawe kelas I B pada bulan April tahun 2020 dan Mengenai Pelaksanaan persidangan secara elektronik pada masa pandemi Covid-19 mulai dari tahap ruang sidang secara elektronik hingga putusan pengadilan. Dan yang terakhir membahas tentang persidangan secara elektronik terhadap terdakwa yang positif Covid-19 yang tata cara pelaksanaannya tidak ada aturan dalam Perma no 4 tahun 2020 tentang administrasi dan persidangan perkara pidana secara elektronik. Dan Mengenai hambatan pelaksanaan persidangan secara elektronik terhadap terdakwa yang positif Covid-19 yaitu petugas kesehatan itu seharusnya ada dokter khusus yang menangani terdakwa positif, dan sarana prasarananya lebih dilengkapkan kembali. Upaya yang harus dilakukan oleh penegak hukum yaitu menjelaskan kepada tersangaka/terdakwa mengenai hak terdakwa dengan jelas, baik itu hak atas dirinya sendiri maupun hak terdakwa melakukan sidang di pengadilan.

\section{SARAN}

Berdasarkan hasil penelitian yang sudah dilakukan maka peneliti memberi saran sebagai berikut:

Perlunya direvis KUHAP dan Perma Nomor 4 tahun 2020 tentang administrasi dan persidangan perkara pidana secara elektronik karena melihat banyak aturan yang belum ada. dan Pelaksanaan mengenai terdakwa yang positif Covid-19 seharusnya diperkuat dengan adanya aturan yang kuat dari penegak hukum agar hak tersangak/terdakwa terpenuhi. Perlunya diberikan sarana dan prasarana untuk berlangsungnya sidang secara elektronik terhadap terdakwa yang positif Covid-19. Aparat penegak hukum harus benarbenar selektif dalam melaksanakan persidangan secara elektronik khususnya untuk terdakwa yang positif Covid-19 


\section{DAFTAR PUSTAKA}

Andi Hamzah, 2008 “Asas-Asas Hukum Pidana” Rineka Cipta, Jakarta.

C.S.T, Kancil, 2002 "Pengantar Ilmu Hukum Dan Tata Hukum Indonesia" Balai Pustaka, Jakarta.

D.Y. Witanto, 2019 "Hukum Acara Praperadilan Dalam Teori Dan Praktek" Imaji Cipta Karya, Kota Depok.

Edy Arm, 2020 “Bukti Elektronik Dalam Praktik Peradilan" Sinar Grafika, Jakarta.

Fakultas Hukum, 2019, "Buku Panduan Penulisan Tugas Akhir Prigram Studi Hukum (S1)" Universitas Malikussaleh, Lhokseumawe.

Fitiani, 2019 "Pengertian Tindak Pidana Khusus" Enam Media, Medan-Sumatera Utara.

Moh. Nazir, 2009 “Metode Penelitian” Ghalia Indonesia, Bogor.

Paulus Effendie Lotulung Dan Sarwono, "Pustaka Peradilan Jilid VIII" Varia Peradilan, Jakarta

R.Suesilo, 2016 "Kitab Undang Undang Hukum Pidana Serta Komentar-Komentarnya Lengkap Pasal Demi Pasal” Politeia, Bogor.

Rocky Marbun, 2015, "Sistem Peradilan Pidana Indonesia" Setara Press, Malang

Suharsimi Arikunto, 2006 "Prosedur Penelitian Suatu Pendekatan Praktik" PT Rineka Cipta, Jakarta.

Suharto dan Efendi Jonaedi, 2010 "Panduan Praktis Bila Anda Menghadapi Perkara Pidana Mulai Proses Penyelidikan Sampai Persidangan", Prestasi Pustaka, Jakarta.

Tata Wijayanta dan Hery Firmansyah, 2011, "Perbedaan Pendapat Dalam Putusan Pengadilan" Pustaka Yustisia, Jakarta Selatan

Teguh Prasetyo, 2018, "Hukum Pidana" PT Raja Grafindo Persada, Jakarta.

Andita Rahma, "Menilai Sidang Daring Berpotensi Maladministrasi", Https://Nasional.Tempo.Co/Read/1351589/Ombudsman-Menilai-SidangDaring-Berpotensi-MaladminiStrasi, Diakses 9 Juni 2020, Pukul 17:36 Pm

Emc, "Pcr Swab Dan Rapid Tes: Apakah Bedanya Dan Bagaimana Prosedurnya" https://ciputrahospital.com/perbedaan-swab-test-pcr-dan-rapid-test/ diakses 05 juni 2020.

Syafira agata ramadhani, 2020. "Asas Asas Hukum Pidana", https://www.menuruthukum.com/2020/05/07/asas-asas-hukum-pidana diakses 7 mei 2020, pukul 12:34 pm

Umi, "metode persidangan, fakultas hukum" https://id.scribd.com/document/ 399017127/Metode-Persidangan, diakses pada 19 Desember 2020 pukul $16: 51$ 